\title{
7. Reproducing Discrimination: Promoting the Equal Sharing of Caring Work in CEDAW, at the ILO and in the $S D A$
}

\author{
Caroline Lambert ${ }^{1}$
}

This chapter is interested in caring work and the impact of reproductive labour on the realisation of substantive equality for women. It will examine the unique approach of the Convention on the Elimination of All Forms of Discrimination Against Women (CEDAW) to reproductive labour and the conjunction of reproductive and productive labour, as well as considering germane International Labour Organisation (ILO) conventions on workers with family responsibilities. Drawing on CEDAW and the ILO, the chapter will put forward a pentamerous schema of obligations that should be realised in Australia and examine the extent to which the Sex Discrimination Act (SDA) achieves these obligations - in particular, the terms and conditions that reflect the needs of workers with family responsibilities in the context of the SDA.

\section{Introduction}

The profile of Australian workplaces has changed significantly in recent years as more women have entered the workforce and more women, and some men, have sought workplaces that better respond to their combined roles as workers and carers of family members. ${ }^{2}$ How has the Sex Discrimination Act 1984 (Cth) (SDA) responded to caring work (commonly practised by women) and to what extent does the $S D A$ reflect the international labour and human rights obligations that relate to this issue?

\footnotetext{
1 This chapter draws on an essay submitted as part of a graduate diploma in international law from the University of Melbourne and my doctoral thesis, also from the University of Melbourne.

2 Sara Charlesworth, 'Managing Work and Family in the "Shadow" of Anti-Discrimination Law' (2005) 23 Law in Context 88; Barbara Pocock, The Work-Life Collision: What Work is doing to Australians and what to do about it, Federation Press, Sydney, 2003; Don Edgar, The War Over Work: The Future of Work and Family, Melbourne University Press, Carlton, 2005.
} 
This chapter is limited to a discussion of the SDA. I note nonetheless that antidiscrimination law is but one aspect of a broader range of legal and policy responses to the needs of workers with family responsibilities. I particularly note that the industrial relations framework, which has been central to the development of terms and conditions supportive of workers with family responsibilities, ${ }^{3}$ falls beyond the purview of this chapter. Likewise, while international legal obligations apply to all jurisdictions - federal, State and Territory - this chapter focuses solely on the provisions of the SDA.

Fundamental to my analysis of the efficacy of the $S D A$ in responding to caring work is an engagement with the figures of the 'ideal worker' and the 'domestic care giver'4 in liberal legal and economic theory. Charlesworth argues that workplaces "continue to be based on the presumption of an "ideal worker" with few domestic responsibilities, full-time work and little or no time off to care for family' ${ }^{5}$ The assumption of course is that the ideal worker has a corollary in the private sphere: the 'full-time carer engaged in family work of housework and childcare, whose unpaid work subsidises the paid work of the ideal worker' ${ }^{6}$ This dichotomy is inherently gendered, with men taking on the ideal worker role and women the domestic caregiver role - the 'mummy track'. ${ }^{7}$

Moreover, while the imperative of economic growth depends on maximising productive labour (which increasingly necessitates harnessing women's labour as well as men's), women who are conscripted to the productive labour market still retain their reproductive labour obligations. Pocock has suggested that while the increased labour force participation by women found a 'happy coconspirator in a market greedy for women's labour... and enthusiastic for the spending power of women's earnings', the market and other social and political institutions were far less responsive to changing the structure and valuation of productive and reproductive labour. ${ }^{8}$ Equally, women's labour force attachment has also been affected by pregnancy-based discrimination and maternitybased discrimination. Despite the existence of social-liberal frameworks to outlaw maternity-based discrimination and pregnancy-based discrimination, they have remained a significant part of many women's productive labour

\footnotetext{
3 For a discussion of the industrial relations system, see: Steve $\mathrm{O}^{\prime}$ Neill, Work and Family Policies as Industrial and Employment Entitlements, Parliamentary Library, Canberra, 2004; Human Rights and Equal Opportunity Commission, Striking the Balance: Women, Men, Work and Family, Discussion Paper, Human Rights and Equal Opportunity Commission, Canberra, 2005, p. 3.

4 Joan Williams, Unbending Gender: Why Work and Family Conflict and What to do About it, Oxford University Press, UK, 2000 (cited in Charlesworth, 'Managing Work and Family in the "Shadow" of AntiDiscrimination Law' 96).

5 Ibid.

6 Joanne Conaghan, 'Women, Work and Family: A British Revolution?' in Joanne Conaghan, Michael Fisch and Karl Klare (eds), Women, Work and Family: A British Revolution?, Oxford University Press, UK, 2004 (cited in Charlesworth, 'Managing Work and Family in the "Shadow" of Anti-Discrimination Law').

7 Human Rights and Equal Opportunity Commission, Striking the Balance, p. 57.

8 Pocock, The Work-Life Collision, p. 8.
} 
experiences, particularly in the private-market sphere. For example, 'business case' arguments have been accepted by courts as a legitimate rationale for maternity-based discrimination, particularly in the context of flexible work arrangements for women with childcare responsibilities (even if they are shortterm responsibilities). ${ }^{9}$

In the first section of this chapter, I will establish the nature of obligations that inhere in the relevant international treaties. I argue that five elements can be discerned in our international legal obligations. These constitute a framework for assessing whether the $S D A$ contributes to the realisation of our international legal obligations with respect to workers with family responsibilities. In particular, I will examine the terms and conditions that reflect the needs of workers with family responsibilities in the context of the SDA.

\section{International Legal Framework}

The focus of this section of the chapter is to inquire into the international legal approach to workers with family responsibilities. Three key treaties are analysed: CEDAW, the Maternity Leave Convention and the Workers with Family Responsibilities Convention.

\section{Women's Labour}

Rights associated with women's labour are articulated in a range of international instruments, within the UN system and also by the ILO. ${ }^{10}$ With the exception of CEDAW and the ILO Convention on Workers with Family Responsibilities, the standards relating to women's labour have typically encompassed productive work. In considering women's experiences of productive work, international legal instruments have addressed a range of non-discrimination issues, including pay equity and conditions at work. The focus on conditions at work has provided

9 For example, Margaret Thornton, 'Feminism and the Changing State: The Case of Sex Discrimination (2006) 21 Australian Feminist Studies 158.

10 The ILO identifies the 'key gender equality conventions' to be the International Labour Organisation Equal Remuneration Convention (Number 100) (adopted 29 June 1951, ILO Document Number C100, entered into force 23 May 1953), the International Labour Organisation Discrimination Convention (Employment and Occupation) (Number 111) (adopted 25 June 1958, ILO Document Number C111, entered into force 15 June 1960), the International Labour Organisation Workers with Family Responsibilities Convention (Number 156) (adopted 23 June 1981, ILO Document Number C156, entered into force 11 August 1983) and the International Labour Organisation Maternity Protection Convention (Number 183) (adopted 15 June 2000, ILO Document Number C183, entered into force 7 February 2002) (International Labour Organisation, Women's Employment: Global Trends and ILO Responses, 49th Session of the Commission on the Status of Women, United Nations, New York, 2005, p. 23). CEDAW, as will be discussed, addresses the issues, as does the International Covenant on Economic, Social and Cultural Rights (ICESCR). For a review and critique of these documents, see: Valerie Oosterveld, 'Women and Employment' in Kelly Askin and Doreen Koenig (eds), Women and International Human Rights Law, Transnational, Ardsley, NY, 1999. 
the entry point for consideration of reproductive labour issues, particularly discrimination on the basis of pregnancy or maternal responsibilities. The best-known example is the ILO Maternity Leave Convention. ${ }^{11}$ The Convention asserts that provision for protection of pregnancy is a shared responsibility of government and society and applies to all women workers (though the definition is limited to those workers with a contractual relationship with an employer, thus excluding self-employed women or women working in family enterprises). The Convention establishes a period of not less than 14 weeks' maternity leave, ${ }^{12}$ including a six-week compulsory minimum period of leave after the birth, ${ }^{13}$ and provides that cash benefits, optimally provided through a compulsory social insurance scheme or public funds, should be available. ${ }^{14}$ In instances where the cash benefits are based on previous earnings, they should not be less than twothirds of the woman's previous earnings. ${ }^{15}$ The Convention also provides that women returning from maternity leave are guaranteed their previous job or an equivalent position at the same rate of pay. ${ }^{16}$ Finally, the Convention provides for breastfeeding breaks for mothers who have returned to work. ${ }^{17}$

Most international legal instruments have, however, struggled to articulate a notion of individual rights or state responsibilities at the point at which reproductive labour obligations have constituted an opportunity cost and have removed (predominantly) women from the productive labour sphere. The opportunity cost extends beyond lost contributions to the productive labour sphere into the loss of women from community building, leadership and political participation. The result has been that reproductive work, where there has been no intersection with the productive labour sphere, has been largely ignored by mainstream UN or ILO treaties.

A striking example of this is the general comment on work issued by the International Covenant on Economic, Social and Cultural Rights (ICESCR) Committee. ${ }^{18}$ While it contains an excellent analysis of the role of governments and private sphere actors in ensuring workers' rights in both the public and private spheres, it does not address the issue of unpaid work (with the exception of gender-neutral discussions of forced labour). The recognition accorded to reproductive labour discrimination is confined to the context of paid labour.

11 The first convention on maternity was adopted by the ILO in 1919 (Convention 3), which was revised in 1952 by Convention 103, and revised again in 2000 (Convention 183).

12 Convention 183, Art. 4(1).

13 Ibid., Art. 4(4).

14 Ibid., Art. 6(8). A subsequent article introduces a progressive realisation component for economies that are insufficiently developed to support such a scheme (at Art. 7).

15 Ibid., Art. 6(3).

16 Ibid., Art. 8(2).

17 Ibid., Art. 10.

18 For example, Committee on Economic, Social and Cultural Rights, General Comment 16, Art 3: The Equal Right of Men and Women to the Enjoyment of All Economic, Social and Cultural Rights, UN Doc E/C 12/2005/3 (2005) (General Comment 16), para. 4. 
Even this approach is limited: the general comment focuses on pregnancy-based discrimination. It ignores issues of maternity-based discrimination and eschews a discussion of family-friendly working practices. ${ }^{19}$

In contrast, the CEDAW Committee has consistently addressed productive and reproductive labour in its General Recommendations and in its Concluding Comments (CCs). Most strikingly, the recognition accorded to women's reproductive work by the CEDAW Committee has been unique. Underpinning the conceptualisation of reproductive and productive labour by the CEDAW Committee is their understanding of gender-based stereotypes and the obligation, established at Article 5, to reconfigure gender relations and to challenge gender-based stereotypes. ${ }^{20}$ In order to understand the conceptualisation of reproductive and productive labour by the CEDAW Committee, I analysed recent CCs and the relevant General Recommendations. ${ }^{21}$ I discerned three themes: views on productive labour; views on the intersection of productive labour and reproductive labour; and views on reproductive labour. In this chapter, I shall focus my analysis on the second two themes.

\section{The Intersection of Productive Labour with Reproductive Labour}

Women's participation in the productive labour force can be significantly affected by two key reproductive labour functions: pregnancy and reproductive labour responsibilities. The relevant provisions of CEDAW include the prohibition of pregnancy-based discrimination, ${ }^{22}$ temporary special measures to protect maternity, ${ }^{23}$ occupational health and safety provisions related to pregnancy and maternity, ${ }^{24}$ education to increase understanding of maternity as a social function $^{25}$ and support for services that enable parents to combine family obligations. ${ }^{26}$

\footnotetext{
19 3D, The Committee on Economic, Social and Cultural Rights: A Compilation of Trade-Related Issues, 3D, Geneva, 2006, para. 13.

20 Committee on the Elimination of All Forms of Discrimination Against Women, General Recommendation Number 25, on Art 4, Paragraph 1, of the Convention on the Elimination of All Forms of Discrimination Against Women, on Temporary Special Measures, UN Doc. A/59/38, 2004 ['CEDAW General Recommendation 25'], paragraph 7.

21 Based on a review of reports available online (<www.bayefsky.com $>$ ), which examined the thematic analysis prepared on 'Work-Equality in the Workplace', 'Pregnancy and Maternity', 'Work-Working Conditions', and 'Work - Right to Work'.

22 Convention on the Elimination of All Forms of Discrimination Against Women, opened for signature 18 December 1979, General Assembly Resolution 34/108; UN General Assembly Official Records, 34th Session, Supplement No. 46, Art. 5(b) (entered into force 3 September 1981), Art. 11.2.a.

23 Ibid., Art. 4.2.

24 Ibid., Art. 11.1.f

25 Ibid., Art. 5.b.

26 Ibid., Art. 11.2.c.
} 
In focusing on the intersection of productive labour with reproductive labour, CEDAW shares some ground with the ILO Convention on Workers with Family Responsibilities in that both treaties call for governments to be more supportive of workers looking after children and immediate family members. Recommended measures include the adoption of anti-discrimination frameworks (specifically to outlaw pregnancy-based and maternity-based discrmination), education programs and childcare and family services. ${ }^{27}$

\section{Reproductive Labour}

The CEDAW Committee has addressed reproductive labour as a stand-alone issue in two key ways: by challenging gendered assumptions about reproductive labour and through an examination of unremunerated reproductive labour in the private sphere. The latter approach in particular has assessed the opportunity costs to women (and the small number of men) who engage in unremunerated reproductive labour.

The CEDAW Committee has articulated a more theorised approach to reproductive labour than the ILO, challenging the social values ascribed to caring labour. For example, the general recommendation on equality in marriage and family relations draws attention to the different value and regulation ascribed to human activities in the public and private spheres. The recommendation acknowledges the lesser value attached to women's labour: 'In all societies women who have traditionally performed their roles in the private or domestic sphere have long had those activities treated as inferior. ${ }^{28}$ The CEDAW Committee has challenged the discriminatory nature of such a practice, pointing to the necessity of these forms of labour as a means for the 'survival of society' ${ }^{29}$

The value of women's reproductive labour has also been raised in the dissenting opinion of CEDAW Committee members, Morvai and Belmihoub-Zerdani, in relation to a complaint submitted under the Optional Protocol to CEDAW. In the complaint, a German woman, Mrs B.-J., disputed the terms of her divorce settlement. Mrs B.-J. was divorced by her husband after 30 years of marriage. She argued that the courts failed to mandate an adequate level of maintenance. She referred to the couple's decision that she would stay at home to raise their children, her husband's resistance to her retraining and her consequent absence from the labour market and the concomitant difficulties she had in finding work subsequent to the divorce. While the majority view of the CEDAW Committee

\footnotetext{
27 See ILO Workers with Family Responsibilities Convention, Articles 1, 2, 3, 4, 5 and 6. See CEDAW, Articles 2, 3 and 11.2.

28 CEDAW Committee 1994, General Recommendation 21, on Equality in Marriage and Family Relations, UN Document Number A/49/38 at 1, paragraph 11.

29 Ibid., para. 12.
} 
found the complaint inadmissible - largely on technical grounds-Morvai and Belmihoub-Zerdani argued that Mrs B.-J.'s husband had 'successfully capitalised the 30 years of unremunerated work of the author', and that a different level of maintenance was mandated. ${ }^{30}$ In effect, Morvai and Belmihoub-Zerdani sought to quantify and differently value Mrs B.-J.'s reproductive labour.

The second way the CEDAW Committee has developed an understanding of reproductive labour is in its reflections on the contours of unremunerated reproductive labour. In particular, the CEDAW Committee has considered the impact of women's unremunerated reproductive labour on women's participation in a range of public and private sphere activities. For example, one general recommendation examines the issue of unpaid women workers in rural and urban family enterprises. It identifies that by working - unpaid - in family enterprises, women are not only being denied a wage (which constitutes a form of exploitation contrary to CEDAW), they are also being denied access to social security and benefits. ${ }^{31}$ Another General Recommendation grapples with the issue of unremunerated work and the failure of governments to address the issue in their reports. It argues that the measurement and quantification of the unremunerated domestic activities of women, which contribute to development in each country, will help to reveal the de facto economic role of women' ${ }^{32}$ This General Recommendation builds on politically negotiated agreements adopted at world conferences on women. The CEDAW Committee has affirmed this approach in a series of CCs. ${ }^{33}$

The CEDAW Committee's understanding of unremunerated reproductive labour has also extended to an analysis of the impacts on women's capacity to contribute to other private and public sphere activities. A recommendation on women in political and public life analyses the impact that reproductive labour has on women's political and public participation:

[I]n all nations, the most significant factors inhibiting women's ability to participate in public life have been the cultural framework of values and

\footnotetext{
30 CEDAW Committee, Report of the Committee on the Elimination of All Forms of Discrimination Against Women, Decision of the Committee on the Elimination of All Forms of Discrimination Against Women, Declaring a Communication Inadmissible under the Optional Protocol to CEDAW, Communication Number 1/2003, Ms B-J $\checkmark$ Germany.

31 CEDAW Committee, General Recommendation 16, on Unpaid Women Workers in Rural and Urban Family Enterprises, UN Document Number A/46/38, 1, United Nations, New York, 1991.

32 CEDAW Committee, General Recommendation 17, on Measurement and Quantification of the Unremunerated Domestic Activities of Women and Their Recognition in the Gross National Product, UN Document Number A/46/38 at 2, United Nations, New York, 1993.

33 CEDAW Committee (Report of the Committee on the Elimination of All Forms of Discrimination Against Women, 28th and 29th Sessions) discussing the reports received from Ukraine (at para. 294), the Czech Republic (at para. 100), Hungary (at para. 328), Albania (at para. 75), Switzerland (at para. 131), Norway (at para. 430), Slovenia (at para. 213), Japan (at para. 370), Estonia (at para. 107).
} 
religious beliefs, the lack of services and men's failure to share the tasks associated with the organization of the household and with the care and raising of children. ${ }^{34}$

The recommendation argues that 'relieving women of some of the burdens of domestic work would allow them to engage more fully in the life of their community'. ${ }^{35}$ It also notes that the economic dependence wrought by this arrangement, in addition to women's double burden of productive and reproductive work, diminishes their political independence and their capacity to fully engage in public life. The recommendation challenges the work cultures associated with public and political work, which, it asserts, manifest in long or inflexible hours. It argues that these factors also inhibit the capacity of women to contribute effectively in public and political work. ${ }^{36}$

\section{International Framework to Reconcile Work-Family Responsibilities}

Taken together, these conventions provide state parties with a comprehensive range of actions that should be taken to enable workers to reconcile work-family responsibilities - specifically

- prohibition of pregnancy-based discrimination in preparing for work, entering into work, participating in work and advancing at work (CEDAW and ILO Maternity Leave Convention)

- provision of paid maternity leave, for a period not less than 14 weeks, with a minimum period of six weeks (CEDAW and ILO Maternity Leave Convention for provision of paid maternity leave; ILO Maternity Leave Convention for time frame)

- terms and conditions that reflect the needs of workers with family responsibilities, including the prohibition of maternity-based discrimination (CEDAW, ILO Maternity Leave Convention [breastfeeding breaks], ILO Workers with Family Responsibilities Convention) and prohibition of family responsibilities being grounds for dismissal (ILO Workers with Family Responsibilities Convention and CEDAW)

- the promotion, development or provision of child and family care by public or private means (CEDAW and ILO Workers with Family Responsibilities Convention)

34 CEDAW Committee, General Recommendation 23, on Women in Political and Public Life, UN Document Number A/52/38/Rev 1, 61, United Nations, New York, 1997, para. 10.

35 Ibid., para. 11.

36 Ibid. 
- education to challenge social, economic and cultural values on family responsibilities and the function of maternity (CEDAW and ILO Workers with Family Responsibilities Convention).

In the remainder of this chapter, I will discuss the positive and negative impacts of the SDA on the terms and conditions that reflect the needs of workers with family responsibilities.

\section{Terms and Conditions that Reflect the Needs of Workers with Family Responsibilities}

Legislative protection of workers with family responsibilities from discrimination has been implemented in various jurisdictions. ${ }^{37}$ At a federal level, Article 8 of the ILO Workers with Family Responsibilities Convention, which provides that family responsibilities shall not constitute a valid reason for termination of employment, ${ }^{38}$ was used as a basis for amending the SDA to incorporate limited protection for workers with family responsibilities. The legislative provision for terms and conditions that reflect the needs of workers with family responsibilities - in particular, the role of anti-discrimination lawis contentious. Employer groups argue that it is inappropriate to further expand anti-discrimination law to provide remedy for a failure to provide flexible workplace terms and conditions. ${ }^{39}$

The ILO Workers with Family Responsibilities Convention does not, however, simply seek to address termination of employment but seeks to obligate state parties to promote laws and policies across a range of workplace behaviours. Likewise, while operating from a paradigm of discrimination against women, CEDAW seeks to alter the 'understanding of maternity as a social function' and to foster 'recognition of the common responsibilities of men and women in the upbringing and development of their children' ${ }^{40}$ To this end, State and Territory legislation provides greater implementation of international legal obligations

37 In New South Wales, discrimination is on the basis of status as a carer; in Victoria, status as a parent or a carer; in Queensland, family responsibilities; in Western Australia, family responsibilities and family status; in Tasmania, family responsibilities; in the Australian Capital Territory, status as a parent or carer; and in the Northern Territory, parenthood. South Australia does not have provisions addressing this issue. State/ territory-based legislation is generally broader than the federal provisions, which are restricted to termination of employment.

38 ILO, Workers with Family Responsibilities Convention, Art. 8.

39 See, for example: Victorian Automobile Chamber of Commerce, Submission to the Human Rights and Equal Opportunity Commission, Striking the Balance: Women, Men, Work and Family, 2005, p. 3; Australian Industry Group, Submission: HREOC Inquiry into Paid Work and Family, 2005, p. 5; Peter Anderson, 'The Sex Discrimination Act: An Employer Perspective-Twenty Years On' (2004) 27 University of New South Wales Law Journal 905.

40 CEDAW, Art. 5. 
than federal legislation, which is restricted to termination of employment. There was intent at the time that this provision be extended further in the future ${ }^{41}$ and the Senate Legal and Constitutional Inquiry into the efficacy of the $S D A$ called for the provisions to be expanded. ${ }^{42}$ The Rudd Government enacted legislation guaranteeing paid parental leave in $2010 .{ }^{43}$

While it is clear that, in a de jure sense, the $S D A$ now meets the obligation to protect workers with family responsibilities from termination of employment by virtue of their family responsibilities, two questions remain. The first is whether the broader provisions on family responsibilities at the international level have been implemented, and the second is whether the judicial interpretation of the de jure provisions contributes to the de facto realisation of the obligations. In the discussion that follows, I will discuss three key issues that arise as limitations to anti-discrimination law

- the challenges of the comparator and causation in the $S D A$

- the limitations of indirect discrimination, including the reasonableness test

- the model of equality pursued.

\section{Challenges Associated with the Comparator and Causation in the $S D$ Family Responsibilities Provisions}

The SDA (ss 7A and 14[3A]) establishes that it is discriminatory behaviour if an employer dismisses an employee with family responsibilities because of their real family responsibilities or because of characteristics that generally appertain to or are imputed to people with family responsibilities. The scope of family responsibilities is defined in Sections 4 and $4 \mathrm{~A}$ and relates to the responsibility to 'care for or support a dependent child or immediate family member, being a spouse, adult child, parent, grandparent, grandchild or sibling of the employee or of a spouse of the employee' ${ }^{44}$ The Human Rights and Equal Opportunity Commission notes that the definition of a de facto spouse is limited to heterosexual relationships. ${ }^{45}$ The judiciary has incorporated constructive dismissal into its understanding of termination of employment, which has enabled its application to a broader range of facts. ${ }^{46}$

\footnotetext{
41 John Von Doussa and Craig Lenehan, 'Barbequed or Burned? Flexibility in Work Arrangements and the Sex Discrimination Act' (2004) 27 University of New South Wales Law Journal 892, 896.

42 Senate Standing Committee on Legal and Constitutional Affairs, Report on the Effectiveness of the Commonwealth Sex Discrimination Act 1984 in Eliminating Discrimination and Promoting Gender Equality, Parliament of Australia, Canberra, 2008, Recommendations 13 and 14; see also Recommendation 30.

43 Paid Parental Leave Act 2010 (Cth).

44 Human Rights and Equal Opportunity Commission, Striking the Balance, p. 83.

45 Ibid.; Von Doussa and Lenehan, 'Barbequed or Burned?' 901-3.

46 Human Rights and Equal Opportunity Commission, Striking the Balance, p. 85.
} 
The case law arising from Sections 7A and 14(3A) has proved controversial for the reasoning associated with identifying the comparator group and factors of causation. ${ }^{47}$ Within the context of the comparator, the dominance of the ideal worker' model has stymied decision makers. Direct discrimination requires that a comparison be made between the complainant and a 'straw group', proving that the complainant would be treated less favourably than the comparator because of family responsibilities. The difficulty has arisen in the identification of the comparator group. In Song $v$ Ainsworth Game Technology Group Pty $L t d$, Raphael FM found that the applicant had been constructively dismissed by reason of direct discrimination on the grounds of family responsibilities. ${ }^{48}$ The applicant was of the view that she had negotiated an arrangement with her employer to leave work between $2.55 \mathrm{pm}$ and $3.15 \mathrm{pm}$ each day to move her son between kindergarten and child care. Her employer disputed the fact that she had negotiated an arrangement and directed her to work the hours as stipulated in her contract: 9 am to 5 pm with a lunchbreak from 12-12.30 $\mathrm{pm}$. The applicant refused and continued to leave work between $2.55 \mathrm{pm}$ and $3.15 \mathrm{pm}$. As a result, the employer determined that her status moved from fulltime to part-time and her hours were reduced from 9 am to $3 \mathrm{pm}$, with a halfhour lunchbreak. ${ }^{49}$ Von Doussa and Lenehan argue that, 'although not entirely clear', it seems that Raphael FM found that the comparator group included such groups of people as 'employees who need to leave the workplace to smoke or were allowed flexibility in their work hours for other reasons'.$^{50}$

In a second case, Evans $v$ National Crime Authority, ${ }^{51}$ the applicant was the primary carer for her toddler child - a responsibility that sometimes necessitated her taking leave. She did so within the parameters of her employment agreement. Her manager was dissatisfied with her use of annual leave, carer's leave and sick leave and was reported to say that if he had known she had childcare responsibilities he would not have employed her. The manager's dissatisfaction was manifested in a poor performance review and shortened contract extensions. ${ }^{52}$ Raphael FM found that the applicant had been constructively dismissed on the basis of both sex and family responsibilities. ${ }^{53}$ Von Doussa and Lenehan argue that Driver FM (this should be Raphael FM) 'correctly identified the comparator as being an employee who took leave within her or his entitlements for reasons unrelated to family responsibilities'. ${ }^{54}$

\footnotetext{
47 Von Doussa and Lenehan, 'Barbequed or Burned?'.

48 Song $v$ Ainsworth Game Technology Pty Ltd (2002) FMCA 31 (Song) [76].

49 Ibid.

50 Von Doussa and Lenehan, 'Barbequed or Burned?' 898.

51 Evans $v$ National Crime Authority (2003) FMCA 375 (Evans).

52 Ibid., [88], [93].

53 Ibid., [106]-[108].

54 Von Doussa and Lenehan, 'Barbequed or Burned?' 898.
} 
Two issues arise. First, Von Dousa and Lenehan argue that the logic in Raphael's finding of the comparator was undermined by his acknowledgment that the respondent had a negative attitude to part-time work of any variety, regardless of motivation. Given the test established for assessment of disadvantage, it is open to suggest that the respondent would have rejected a request for part-time work from any employee..$^{55}$ Von Doussa and Lenehan argue that the approach taken by Raphael (not Driver) is more satisfactory and, subject to caveats, could provide the basis for working fathers to challenge refusal to countenance parttime work. ${ }^{56}$ The second issue relates to Raphael FM's seeming identification of the comparator group as including those who require flexible work arrangements to accommodate smoking. The issue arose because it appears the company had a policy of allowing workers to take 20-minute smoking breaks. Thus, in identifying comparator groups within the workplace, it was open to Raphael FM to draw on such a group. Nonetheless, the identification of this group as a comparator points to the challenges of the comparator requirement. The family responsibilities provisions seek to address endemic and structural discrimination against a particular group of people in our community, whoworkforce participation figures suggest - are regularly discriminated against in the context of full-time employment. ${ }^{57}$ The comparator element requires that this level of discrimination be assessed against an alternative group, smokers, who do not seem to experience the same level of discrimination in seeking fulltime employment, though they are increasingly being required to smoke further and further away from their desks.

Finally, and briefly, Von Doussa and Lenehan argue, citing Song and Escobar, ${ }^{58}$ that case law has demonstrated challenges associated with the concept of causation in family responsibility claims. They suggest that there is very often a lack of clarity around refusals to envisage flexible work practices and that this could pose 'difficulties in the terms of causation'. ${ }^{59}$

\section{Limitations of Indirect Discrimination}

Given the limitations inherent in the restriction of family responsibilities provisions to direct discrimination, ${ }^{60}$ the Human Rights and Equal Opportunity Commission notes that

\footnotetext{
55 Ibid., 899.

56 Ibid., 900.

57 Pocock, The Work-Life Collision, p. 34.

58 In this case, an employee was found to have been discriminated against on the basis of family responsibilities and sex when she sought to return to work part-time at the conclusion of her maternity leave, was denied and had her employment terminated. Escobar $v$ Rainbow Printing Pty Ltd (No. 2) (2002) FMCA 122 (Escobar) [36].

59 Von Doussa and Lenehan, 'Barbequed or Burned?' 900.

60 Human Rights and Equal Opportunity Commission, Striking the Balance, p. 83.
} 
rather than relying on the limited family responsibilities provisions, many women complainants are using the sex and pregnancy discrimination provisions of the SDA to pursue allegations of workplace failure to accommodate family responsibilities. In particular, the indirect sex and pregnancy discrimination provisions of the SDA have proved useful to complainants. ${ }^{61}$

Sections 5(2) and 7(B1) are the relevant provisions in the SDA, defining indirect discrimination and the reasonableness test, respectively. Several cases are germane: ${ }^{62}$ Hickie $v$ Hunt and Hunt, ${ }^{63}$ Mayer $v$ Australian Nuclear Science and Technology Organisation, ${ }^{64}$ Escobar $v$ Rainbow Printing Pty Ltd ${ }^{65}$ Howe $v$ Qantas Airways $L t d^{66}$ and Kelly $v$ TPG Internet Pty Ltd. ${ }^{67}$ These cases have explored the principle that women returning to work after maternity leave should be able to negotiate flexible terms that enable them to maintain a workforce attachment and meet family care responsibilities. A central component of the cases has been the judicial notice that far more women than men seek part-time work to enable them to care for young children. Thus, in Hickie, refusal to provide for part-time work arrangements constituted indirect discrimination on the basis of sex. ${ }^{68} \mathrm{In}$ Hickie, Commissioner Evatt asserted that it was 'general knowledge that women are far more likely than men to require at least some periods of part-time work during their career, and in particular a period of part-time work after maternity leave in order to meet family responsibilities' ${ }^{69}$

This statement has become the authoritative articulation of the issue. In Mayer, Driver FM drew on Hickie in finding that the applicant had experienced indirect sex discrimination on the basis that she was denied available part-time work, which would have enabled her to reconcile work and family responsibilities. ${ }^{70}$ In Howe, however, a more limited approach was taken. While Driver FM found that the respondent had subjected the applicant to pregnancy-based discrimination in failing to allow her to access sick leave when pregnancy stopped her from

\footnotetext{
61 Ibid., p. 85.

62 Given the focus of this chapter on federal anti-discrimination law, several relevant cases from State/ Territory jurisdictions have been excluded from discussion. The most important of these relate to the litigation of Ms Schou against the State of Victoria. For excellent articles on the issues raised and implications, please see: Therese MacDermott and Rosemary Owens, ‘Recent Cases: Equality and Flexibility for Workers with Family Responsibilities: A Troubled Union?' (2000) 13 Australian Journal of Labour Law 20; Beth Gaze, 'Context and Interpretation in Anti-Discrimination Law' (2002) 26 Melbourne University Law Review 325; Fiona Knowles, 'Misdirection for Indirect Discrimination' (2004) 17 Australian Journal of Labour Law 1; Margaret Thornton, 'Feminism and the Changing State' (2006) 21 Australian Feminist Studies 151.

63 Hickie $v$ Hunt \& Hunt [1998] HREOCA 8 (Hickie).

64 Mayer $v$ Australian Nuclear Science and Technology Organisation (2003) FMCA 209 (Mayer).

65 Escobar.

66 Howe $v$ Qantas Airways Lt, (2004) FMCA 242 (Howe).

67 Kelly $v$ TPG Internet Pty Ltd (2003) FMCA 584 (Kelly).

68 Hickie [6.17.12].

69 Ibid. [6.17.10].

70 Mayer [75].
} 
flying, he dismissed the claim that the respondent's refusal to provide the applicant part-time work at the previous level constituted constructive dismissal on the grounds of indirect sex discrimination. ${ }^{71}$ Nonetheless, he did assert that

family responsibilities is not necessarily a characteristic appertaining generally to women. The point is that the present state of Australian society shows that women are the dominant caregivers to young children. While that position remains (and it may well change over time) s5(2) of the SDA operates to protect women against indirect sex discrimination in the performance of that care giving role. ${ }^{72}$

Nonetheless, as shall be discussed below, Driver FM still dismissed the application for indirect discrimination on the basis that the respondent did not impose a condition of full-time work and was unable to offer part-time work at the previous level because of conditions established in the enterprise bargaining agreement. ${ }^{73}$ In Kelly, Raphael FM argued that a part-time return to work after maternity leave was a benefit rather than a condition or requirement. ${ }^{74}$ This judgment has been distinguished subsequently by Driver FM in Howe and caution has been expressed by lawyers and academic publications as to its veracity. ${ }^{75}$ The question of whether the $S D A$ provides for a part-time return to work from maternity leave on the basis of family responsibilities remains unresolved.

Finally, recourse to the claim of indirect discrimination necessitates engagement with the reasonableness test. Von Doussa and Lenehan suggest that the reasonableness test has constituted a less significant barrier at the federal level than State levels. ${ }^{76}$ At the federal level, Mayer upheld the validity of business needs in the reasonableness test, as, to a certain extent, did Howe. ${ }^{77}$ Nonetheless, the significant detriment that the reasonableness test has caused in the Schou cases in Victoria suggests quite major limitations to the anti-discrimination framework in the context of family responsibilities. ${ }^{78}$

\section{Equality Models}

One of the most significant challenges that arises in the context of the family responsibilities cases is the model of equality that is being promoted through

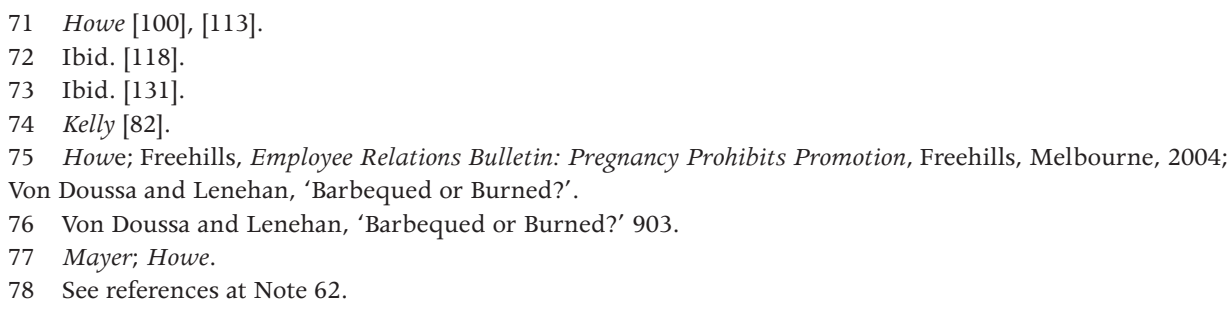


the decisions and the legislative provisions. Two issues arise: first, the reliance (touched on above) of indirect sex discrimination claims on formal equality in promoting the view that women are the primary care givers. Second, the promotion of a formal model of equality in the line of reasoning associated with the test of reasonableness.

The CEDAW Committee has asserted, very strongly, that a formal equality approach will not satisfy the realisation of CEDAW obligations: identical treatment will not suffice, rather biological, social and cultural constructions of difference must be addressed along with a contextual consideration of the gender differences so as to ensure that measures go 'towards a real transformation of opportunities, institutions and systems so that they are no longer grounded in historically determined male paradigms of power and life patterns' ${ }^{\prime 9}$ This, combined with the CEDAW obligations in challenging the gendered representation of family responsibilities, results in a clear expectation that for substantive equality to be achieved laws, policies and programs will need to transform social relations. In their review of court cases on family responsibilities under the indirect sex discrimination provisions of the SDA, Von Doussa and Lenehan note, however, that there could be some limitation to the legal reasoning. ${ }^{80}$ The reliance on Evatt's articulation of sex discrimination on the basis of women's familial responsibilities has the potential to harden community and judicial perceptions that women are the 'natural' providers of care for small children. ${ }^{81}$ The Human Rights and Equal Opportunity Commission concurs and notes that ' $[\mathrm{t}]$ ogether with workplace cultures that may discourage men from claiming a better balance between their paid work and family responsibilities, this failure of the federal anti-discrimination framework effectively locks men into the breadwinner model' ${ }^{82}$

While the indirect discrimination provisions of the SDA are commonly understood to be working towards the achievement of substantive equality, in this instance they contribute to the perpetuation of particular ideas about natural caring capacities of women over men. They therefore do not meet the measure of substantive equality established in the CEDAW General Recommendation on Temporary Special Measures.

The second issue that arises relates to the model of equality being pursued in some of the findings around reasonableness. In Howe, Driver FM asserted that the facts did not support a finding of indirect discrimination. In the absence of part-time work at the level at which she had previously been employed, the applicant chose to take a demotion because the lower position provided her

79 CEDAW Committee, 'General Recommendation 25', paras 8, 10.

80 Von Doussa and Lenehan, 'Barbequed or Burned?' 901.

81 Ibid.

82 Human Rights and Equal Opportunity Commission, Striking the Balance, p. 86. 
with increased flexibility. Rather than acknowledging the invidiousness of the decision the applicant was forced to make, Driver FM asserts that 'the applicant has chosen to characterise that transfer as a "demotion" but, if it was, it was a demotion that the applicant sought and was granted in order to give her the flexibility she needed to provide care for her young second child' ${ }^{83}$

It is not beyond the realms of interpretation to infer from this that Driver FM is of the view that the quality of a woman's workforce attachment is of little relevance as long as her workforce attachment is maintained. He seems to suggest that having satisfying work that will contribute to progression rather than regression in a career is to be sacrificed at the altar of family responsibilities. A similar view is propounded in Mayer, where business needs were used by the respondent, and accepted by Driver FM, as a reason for denying that the applicant could have returned to work in her former position. The possibility of a flexible workplace response - for example, a job-sharing situation - was rejected by Dr Carr and Driver FM asserted that 'his views are certainly reasonable' in this regard. ${ }^{84}$ Both these views undermine the transformation of workplace culture to one that would contribute to the realisation of the substantive equality objective of CEDAW. In this respect, the figures of the 'ideal worker' and 'domestic care giver' are not so much challenged as reinscribed.

From the discussion above, it can be seen that, at a federal level, provisions on family responsibilities and indirect sex discrimination have begun to contribute to the implementation of the ILO Workers with Family Responsibilities obligations on more flexible workplace practices. Nonetheless, limitations to the grounds for complaint and requirements to identify a comparator group, challenges with causation and the indirect sex discrimination approach along with the prevalence of a formal model of equality all negatively impact on the full realisation of the ILO and CEDAW obligations to transform work practices to better respond to the needs of workers with family responsibilities.

\section{Conclusion}

What conclusions can be drawn from this discussion about the contribution of sex discrimination law to the implementation in Australia of international legal obligations relating to workers with family responsibilities? To what extent does the $S D A$ contribute to the implementation of international legal obligations pertaining to the terms and conditions that reflect the needs of workers with family responsibilities, including the prohibition of maternitybased discrimination and prohibition of family responsibilities being grounds

83 Howe [131].

84 Mayer [66]. 
for dismissal? As noted, the SDA proscribes direct discrimination on the basis of family responsibilities in the context of termination of employment. The indirect sex discrimination provisions of the SDA have also been interpreted to provide remedies against workplace practices that have discriminated against female workers with family responsibilities. A legal lacuna remains, however, for male workers with family responsibilities, and at one level the provisions in the SDA in fact contribute to the perpetuation of women as the primary care givers and a model of formal as opposed to substantive equality. In addition, the failure to enact broader provisions in the context of family responsibilities (that is, to extend them beyond termination of employment and direct discrimination) has limited the de jure implementation of the international obligations. Similar challenges to those described in relation to pregnancy-based discrimination exist in the context of the de facto realisation of the rights. As the federal government considers its response to the senate inquiry into the efficacy of the $S D A$, it would do well to remedy the shortcomings of the $S D A$ for workers with family responsibilities.

\section{Bibliography}

\section{Books and articles}

3D, The Committee on Economic, Social and Cultural Rights: A Compilation of Trade-Related Issues, 3D, Geneva, 2006.

Anderson, Peter, 'The Sex Discrimination Act: An Employer PerspectiveTwenty Years On' (2004) 27 University of New South Wales Law Journal 905.

Charlesworth, Sara, 'Managing Work and Family in the "Shadow" of AntiDiscrimination Law' (2005) 23 Law in Context 88.

Conaghan, Joanne, 'Women, Work and Family: A British Revolution?' in Joanne Conaghan, Michael Fisch and Karl Klare (eds), Women, Work and Family: A British Revolution?, Oxford University Press, UK, 2004.

Edgar, Don, The War Over Work: The Future of Work and Family, Melbourne University Press, Carlton, 2005.

Gaze, Beth, 'Context and Interpretation in Anti-Discrimination Law' (2002) 26 Melbourne University Law Review 325.

Knowles, Fiona, 'Misdirection for Indirect Discrimination' (2004) 17 Australian Journal of Labour Law 185. 
Sex Discrimination in Uncertain Times

MacDermott, Therese and Owens, Rosemary, 'Equality and Flexibility for Workers with Family Responsibilities: A Troubled Union?' (2000) 13 Australian Journal of Labour Law 278.

O'Neill, Steve, Work and Family Policies as Industrial and Employment Entitlements, Parliamentary Library, Canberra, 2004.

Oosterveld, Valerie, 'Women and Employment' in Kelly Askin and Doreen Koenig (eds), Women and International Human Rights Law, Transnational, Ardsley, NY, 1999.

Pocock, Barbara, The Work-Life Collision: What Work is doing to Australians and what to do about it, Federation Press, Sydney, 2003.

Thornton, Margaret, 'Feminism and the Changing State: The Case of Sex Discrimination' (2006) 21 Australian Feminist Studies 151.

Von Doussa, John and Lenehan, Craig, 'Barbequed or Burned? Flexibility in Work Arrangements and the Sex Discrimination Act' (2004) 27 University of New South Wales Law Journal 892.

Williams, Joan, Unbending Gender: Why Work and Family Conflict and What to Do About It, Oxford University Press, UK, 2000.

\section{Legislation}

Paid Parental Leave Act 2010 (Cth)

Sex Discrimination Act 1984 (Cth)

\section{Cases}

Escobar v Rainbow Printing Pty Ltd (No. 2) (2002) FMCA 122

Evans v National Crime Authority (2003) FMCA 375

Hickie $v$ Hunt \& Hunt (1998) 92-910 EOC

Howe v Qantas Airways Ltd (2004) FMCA 242

Kelly v TPG Internet Pty Ltd (2003) FMCA 584

Mayer $v$ Australian Nuclear Science and Technology Organisation (2003) FMCA 20.

Song $v$ Ainsworth Game Technology Pty Ltd (2002) FMCA 31 


\section{Reports and miscellaneous primary sources}

Australian Industry Group, Submission: HREOC Inquiry into Paid Work and Family, 2005, <http://www.humanrights.gov.au/sex_discrimination/ publication/strikingbalance/submissions/>

Committee on Economic, Social and Cultural Rights, General Comment 16, Art 3: The Equal Right of Men and Women to the Enjoyment of All Economic, Social and Cultural Rights, UN Doc E/C 12/2005/3, United Nations, New York, 2005.

Committee on the Elimination of All Forms of Discrimination Against Women, General Recommendation 16, on Unpaid Women Workers in Rural and Urban Family Enterprises, UN Document Number A/46/38, United Nations, New York, 1991.

Committee on the Elimination of All Forms of Discrimination Against Women, General Recommendation 17, on Measurement and Quantification of the Unremunerated Domestic Activities of Women and Their Recognition in the Gross National Product, UN Document Number A/46/38, United Nations, New York, 1993.

Committee on the Elimination of All Forms of Discrimination Against Women, General Recommendation 21, on Equality in Marriage and Family Relations, UN Document Number A/49/38, United Nations, New York, 1994.

Committee on the Elimination of All Forms of Discrimination Against Women, General Recommendation 23, on Women in Political and Public Life, UN Document Number A/52/38/Rev 1, United Nations, New York, 1997.

Committee on the Elimination of All Forms of Discrimination Against Women, Report of the Committee on the Elimination of All Forms of Discrimination Against Women, Decision of the Committee on the Elimination of All Forms of Discrimination Against Women, Declaring a Communication Inadmissible under the Optional Protocol to CEDAW, Communication Number 1/2003, Ms $B-J v$ Germany, United Nations, New York, 2003.

Committee on the Elimination of All Forms of Discrimination Against Women, General Recommendation Number 25, on Art 4, Paragraph 1, of the Convention on the Elimination of All Forms of Discrimination Against Women, on Temporary Special Measures, UN Doc. A/59/38, United Nations, New York, 2004.

Convention on the Elimination of All Forms of Discrimination Against Women, Opened for signature 18 December 1979, General Assembly Resolution 
34/108, UN General Assembly Official Records, 34th Session, Supplement No. 46, Art. 5(b) (entered into force 3 September 1981), United Nations, New York.

Freehills, Employee Relations Bulletin: Pregnancy Prohibits Promotion, Freehills, Melbourne, 2004.

Human Rights and Equal Opportunity Commission, Striking the Balance: Women, Men, Work and Family, Discussion Paper, Human Rights and Equal Opportunity Commission, Sydney, 2005.

International Labour Organisation, Equal Remuneration Convention 100, Adopted 29 June 1951, ILO Document Number C100, Entered into force 23 May 1953, International Labour Organisation, Geneva, 1951.

International Labour Organisation, Discrimination Convention (Employment and Occupation) 111, Adopted 25 June 1958, ILO Document Number C111, Entered into force 15 June 1960, International Labour Organisation, Geneva, 1958.

International Labour Organisation, Workers with Family Responsibilities Convention 156, Adopted 23 June 1981, ILO Document Number C156, Entered into force 11 August 1983, International Labour Organisation, Geneva, 1981.

International Labour Organisation, Maternity Protection Convention 183, Adopted 15 June 2000, ILO Document Number C183, Entered into force 7 February 2002, International Labour Organisation, Geneva, 2002.

International Labour Organisation, Women's Employment: Global Trends and ILO Responses, 49th Session of the Commission on the Status of Women, United Nations, New York, 2005.

Senate Standing Committee on Legal and Constitutional Affairs, Report on the Effectiveness of the Commonwealth Sex Discrimination Act 1984 in Eliminating Discrimination and Promoting Gender Equality, Parliament of Australia, Canberra, 2008.

Victorian Automobile Chamber of Commerce, Submission to the Human Rights and Equal Opportunity Commission: Striking the Balance: Women, Men, Work and Family, <http://www.humanrights.gov.au/sex_discrimination/ publication/strikingbalance/submissions/> 